\title{
Evaluation of comorbidity in patients with alcoholic cirrhosis of the liver associated with non-alcoholic fatty liver disease
}

\author{
N. R. Matkovska*1,A,B,D , N. H. Virstiuk ${ }^{1, A, E, F}$, U. V. Balan ${ }^{1,2, B, D}$ \\ ${ }^{1}$ Ivano-Frankivsk National Medical University, Ukraine, ${ }^{2}$ Regional Clinical Hospital, Ivano-Frankivsk, Ukraine
}

A - research concept and design; B - collection and/or assembly of data; C - data analysis and interpretation; D - writing the article;

$\mathrm{E}$ - critical revision of the article; $\mathrm{F}$ - final approval of the article

Key words: alcoholic liver disease, nonalcoholic fatty liver disease, cirrhosis, comorbidity.

\section{Zaporozhye} medical journal 2020; $22(2), 166-173$

*E-mail: nmail4you@gmail.com
The aim of the study was to evaluate the concomitant pathology in patients with alcoholic cirrhosis of the liver associated with non-alcoholic fatty liver disease, depending on the compensation of the disease and patient's age.

Material and methods of research. The study included 204 patients. Among them, 78 patients (Group I) had alcoholic liver cirrhosis (ALC) and 126 patients (Group II) had a combination of ALC with non-alcoholic fatty liver disease (NAFLD). Patients were subgrouped according to compensation classes by the Child-Pugh score $(\mathrm{A}, \mathrm{B}, \mathrm{C})$. To evaluate comorbidity, CirCom, $\mathrm{CCl}$, $\mathrm{ECl}$ indices were used.

Results. More than $70 \%$ of patients of group II had concomitant diseases (CD) and cardiovascular complications. They also suffered from pleurisy, pneumonia, spontaneous bacterial peritonitis more frequently.

$46 \%$ of patients of groups IIA+B, who were less than 45 years old, had two $C D$, which 2.6 times exceeded the number of such persons in group I. More than $80 \%$ of middle-aged patients in group IIA+B had more than $3 \mathrm{CD}$, which is 1.7 times more than in group I. $70 \%$ of patients of group II at the stage of decompensation of cirrhosis had 5 or more CD. The direct relationship between the age of patients and the number of $C D$, as well as between the degree of compensation and the amount of $C D$ leads to a more severe course of the disease in people of group II.

The significant correlation between the $\mathrm{CCl}, \mathrm{ECl}$, CirCom scales and the Child-Pugh degree of the disease severity was detected. The number of concomitant pathologies in patients suffering from liver cirrhosis (LC) significantly increased the risk of death from the causes which are not related to LC (RR: $5.872 ; 95 \%$ Cl: 1.866-18.477). 4-year observation showed that $80.6 \%$ patients of group II have died, which 4 times exceeded the number of those who had ALC.

Conclusions. Most patients of group II had cardiovascular diseases. They had disorders of the respiratory, urinary, endocrine, nervous systems, as well as bacterial complications, more frequently. It is useful to use the $\mathrm{CCl}, \mathrm{ECl}$, CirCom scales of comorbidity, and Child-Pugh degree of the disease severity in considering the comorbidity level and severity of the disease.

The incidence of $C D$ increases with age and significantly increases the risk of death from causes which are not associated with the complications of the LC.
Киючові слова: алкогольна хвороба печінки, неалкогольна жирова хвороба печінки, цироз печінки, коморбіАність.

Запорізький медичний журнал. 2020. T. 22, № 2(119) C. $166-173$

\section{Оцінювання коморбідності у хворих на алкогольний цироз печінки в поєАнанні з неалкогольною жировою хворобою печінки}

\section{Н. Р. Матковська, Н. Г. Вірстюк, У. В. Балан}

Мета роботи - оцінювання супутньої патології у хворих на алкогольний цироз печінки при поєднанні з неалкогольною жировою хворобою печінки залежно від компенсації захворювання та віку пацієнтів.

Матеріали та методи. Обстежили 204 пацієнти. Серед них у 78 осіб (I група) діагностували алкогольний цироз печінки (АЦП), у 126 осіб (ІІ група) було поєднання АЦП із неалкогольною жировою хворобою печінки (НАЖХП). Пацієнтів поділили на підгрупи залежно від класів компенсації за критеріями Чайльд-П'ю (А, В, С). Для оцінювання коморбідності використовували індекси CirCom, $\mathrm{CCl}$ та ECl.

Результати. Понад 70 \% пацієнтів II групи мали супутні захворювання (С3) та їхні ускладнення з боку серцево-судинної системи (ССС). У них також частіше виникали плеврит, пневмонії, спонтанний бактеріальний перитоніт.

У пацієнтів IIA+B груп віком менше ніж 45 років 2 С3 було у $46 \%$ осіб, що у 2,6 раза більше, ніж кількість таких осіб I групи. Понад 80 \% пацієнтів ІІА+В групи середнього віку мали більше ніж 3 С3, що в 1,7 раза перевищує кількість таких осіб I групи. 70 \% пацієнтів II групи на стадії декомпенсації мали 5 і більше С3. Прямий зв'язок між віком хворих і кількістю С3, а також між ступенем компенсації та кількістю СЗ зумовлює істотно важчий перебіг в осіб II групи.

Виявили вірогідний кореляційний зв'язок між шкалами СCl, ECl, CirCom і ступенем важкості за шкалою Чайлд-П'ю. Кількість C3 вірогідно збільшувала ризик смерті від причин, що не пов'язані з цирозом печінки (ЦП) (RR: 5,872; 95 \% Cl: 1,866-18,477). Протягом 4 років спостереження з-поміж пацієнтів II групи померли 80,6 \% осіб, що в 4 рази більше, ніж у I групі.

Висновки. У більшості пацієнтів II групи були захворювання ССС. У них частіше виникали порушення з боку дихальної, сечовивідної, ендокринної, нервової систем, а також бактеріальні ускладнення. Корисним є використання шкал $\mathrm{CCl}, \mathrm{ECl}$, CirCom і Чайлд-П'ю для врахування рівня коморбідності та важкості захворювання.

Частота СЗ збільшується з віком і вірогідно збільшує ризик смерті від причин, що не пов'язані з ускладненнями ЦП. 


\section{Оценка коморбидности у больных с алкогольным циррозом печени в сочетании с неалкогольной жировой болезнью печени}

\section{Н. Р. Матковская, Н. Г. Вирстюк, У. В. Балан}

Цель работы - оценка сопутствующей патологии у больных с алкогольным циррозом печени при сочетании с неалкогольной жировой болезнью печени в зависимости от компенсации заболевания и возраста пациентов.

Материалы и методы. Обследованы 204 пациента. Среди них у 78 человек (I группа) диагностирован алкогольный цирроз печени (АЦП), у 126 больных (ІІ группа) было сочетание АЦП с неалкогольной жировой болезнью печени (НАЖБП). Пациентов разделили на подгруппы в зависимости от классов компенсации по критериям Чайльд-Пью (А, В, С). Для оценки коморбидности использовали индексы CirCom, CCI и ECI.

Результаты. Более 70 \% пациентов II группы имели сопутствующие заболевания (С3) и их осложнения со стороны сердечно-сосудистой системы (ССС). У них также чаще возникали плеврит, пневмония, спонтанный бактериальный перитонит. У пациентов ПА+В групп в возрасте менее 45 лет 2 С3 было у $46 \%$, что в 2,6 раза превышает количество таких больных I группы. Более 80 \% пациентов ПА+В группы среднего возраста имели более 3 С3, что в 1,7 раза превышает количество таких больных I группы. 70 \% пациентов II группы в стадии декомпенсации имели 5 и более СЗ. Прямая связь между возрастом больных и количеством С3, а также между степенью компенсации и количеством С3 обусловливает более тяжелое течение у пациентов II группы. Установлена достоверная корреляционная связь между шкалами $\mathrm{CCl}, \mathrm{ECl}$, CirCom и степенью тяжести по шкале Чайлд-Пью. Количество С3 достоверно увеличивало риск смерти от причин, не связанных с циррозом печени (ЦП) (RR: 5,872; 95 \% Cl: 1,866-18,477). В течение 4 лет наблюдений среди пациентов II группы умерли 80,6 \%, что в 4 раза превысило количество умерших I группы.

Выводы. У большинства пациентов II группы были заболевания ССС. У них чаще возникали нарушения со стороны дыхательной, мочевыделительной, эндокринной, нервной систем, а также бактериальные осложнения. Полезно использование шкал $\mathrm{CCl}$, ECl, CirCom и Чайлд-Пью для учета уровня коморбидности и тяжести заболевания. Частота СЗ увеличивается с возрастом и достоверно увеличивает риск смерти от причин, не связанных с осложнениями ЦП.

One of the priorities of the European Health Strategy 2020 is to curb the development of non-communicable diseases epidemics, which requires the use of an integrated approach to promote increase and strengthen public health. Due to the introduction of health care reform, this approach is implemented by reorienting the medical sector to the priority of ambulatory care. The latter aims at preventing the emergence and progression of diseases due to external causes and behavioural factors of illness, among which the most common are the use of tobacco and alcohol, obesity, low level of physical activity, high levels of stress. Such factors lead to the development of pathological conditions, which are caused not only by the deterioration of the quality of life but also by the causes of high mortality. Among the causes of mortality there are endogenous (circulatory and neoplastic diseases) and exogenous (external, respiratory, digestive, infectious and parasitic diseases) factors [1].

The mortality rates of Ukraine's population in recent years have been extremely disappointing and are among the highest in Europe and in the world. In particular, the overall mortality rate is constantly increasing, and the average life expectancy is low. Regarding the last indicator, according to European standards, it is very low and lagging most developed countries, sometimes exceeding 10, and in men - almost 15 years [2].

The isolated nosological unit is very rare in chronic pathologies. A significant number of people with chronic diseases have more than one disorder that can be interconnected or independent of each other, which affects not only the individual patient's prognosis, but also has a significant impact on the health of the nation and the socio-economic implications for general population level [3,4]. In recent years, large-scale research in this direction has been carried out, evidence base and patient management guidelines considering comorbidity are being developed. In cases of combined pathology many diseases become atypical, which leads to deterioration of the disease, increased risk of complications and mortality, exacerbation of the issue of polypharmacy, and reduced patient adherence to medical treatment $[5,6]$.

The prevalence of comorbidity is $20-30 \%$ of the total population and 55-98 \% among the elderly. The number of chronic diseases varies from 2.8 in patients aged 18-44 years to 6.4 in patients over 65 years of age. The incidence of combined illnesses increases with age: from $10 \%$ at the age of 19 years and up to $80 \%$ for the elderly people [7]. The problem of comorbidity as a result of the interaction of major clinical factors of various diseases leads to the emergence of new clinical symptoms and syndromes. Some researchers describe comorbidity as a symptom-complex of a new nosological unit characterized by a single pathogenetic mechanism. However, there are many combined states in which it is impossible to determine whether there is a causal relationship between them, or not [8-10].

The high prevalence of combined pathology with diseases of the digestive system predetermines increased attention of scientists and researchers to this problem. A special place belongs to the study of liver diseases, which is due to the multifunctionality of this organ. One of the most common pathologies is alcoholic liver disease (ALD). The fact of direct and indirect effects of alcohol on the structure and function of not only the liver, but also other organs, remains undeniable. However, ALD is the most prognostically unfavourable complication of alcoholism. The literature describes the comorbid states associated with ALD, among which there are two categories: the first - direct complications of alcoholism: alcoholic cardiomyopathy, myopathy, Korsakov's psychosis, chronic cerebral dysfunction, alcoholic cerebellar degeneration, peripheral neuropathy, chronic pancreatitis, malnutrition, osteopenia; the second category - diseases that are common in alcoholics, among which other diseases of the liver, chronic hepatitis $\mathrm{C}$, coronary artery disease, hepatocellular carcinoma [11,12].
Ключевые слова:

алкогольная

болезнь печени, неалкогольная жировая болезнь печени, цирроз печени, коморбиАНОсть.

\section{Запорожский} медицинский журнал. 2020. T. 22, № 2(119). C. $166-173$ 
In recent years, reports on non-alcoholic fatty liver disease (NAFLD) have been published more often. Its considerable prevalence makes it pandemic. But its frequent combination with other pathologies is considered prognostically unfavourable. Studies show that the pathogenetic processes of ALD and NAFLD have similar mechanisms and are associated with lipid and carbohydrate metabolism disorders, the development of oxidative stress, the immune-inflammatory response, the activation of fibrosis and apoptosis, and vascular lesion. Both diseases have an effect not only on the liver as a target organ, but on the whole organism, considering them multisystemic $[13,14]$. Therefore, the characteristics of comorbidity and its influence on the prognosis of the course of ALD associated with the NAFLD, remain relevant.

\section{The aim}

To evaluate the concomitant pathology in patients with alcoholic cirrhosis of the liver associated with NAFLD, depending on the compensation of the disease and patient's age.

\section{Material and methods}

The study included 204 patients with diagnosed liver cirrhosis (LC), who underwent inpatient treatment in the gastroenterology department of the Ivano-Frankivsk Regional Clinical Hospital. Among them 78 patients had ALD at the stage of the LC (Group I) and 126 patients had a combination of ALD with NAFLD (Group II). Among the patients in group I, there were 24 women and 54 men $53.2 \pm 11.4$ years old with an average duration of the disease $5.9 \pm 2.1$ years; among patients of group II there were 22 women and 104 men $47.8 \pm 9.4$ years old and average duration of the disease was $4.2 \pm 2.7$ years. Patients of groups I and II were subgrouped according to LC compensation classes by the Child-Pugh score: IA (17 people), IB (38 people), IC (23 people); IIA (44 people), IIB (48 people), IIC (34 people). The diagnosis was verified using clinical, laboratory and instrumental methods in accordance with the order of the Ministry of Health of Ukraine No. 826 dated November 6, 2014, adapted clinical guidelines "Non-Alcoholic Fatty Liver Disease", adapted clinical guidelines "Alcoholic Liver Disease", 2014, adapted clinical guidelines "Cirrhosis of the Liver", 2017 (State Expert Centre of the Ministry of Health of Ukraine, Ukrainian Gastroenterology Association, Kyiv), recommendations of the European Association for the Study of Liver, Diabetes and Obesity (EASL-EASD-EASO, 2016).

Common clinical examinations, ultrasound examination of the abdominal cavity, esophagogastroduodenoscopy were performed. To detect the alcoholic aetiology of the disease, according to the recommendations of the World Health Organization, more than 2 doses of alcohol (1 standard dose $=10 \mathrm{~g}$ of ethyl alcohol) per day for women and more than 4 doses for men were taken into account; and CAGE (Cut, Annoyed, Guilty, Eye-opener), AUDIT (Alcohol Use Disorders Identification Test, 1989), the PAS questionnaire (post-alcohol syndrome developed by P. P. Ogurtsov, A. B. Pokrovsky, A. E. Uspensky), LeGo (PM LeGo (1976) in the modification of O. B. Zharkov, 2000) were used; as a method of non-invasive evaluation of the aetiology of alcoholic and non-alcoholic liver damage, the index ANI
(Alcoholic liver disease/non-alcoholic fatty liver disease index, 2006) was used. Exclusion criteria included cirrhosis of the viral, toxic, autoimmune genesis, metabolic diseases of the liver, oncological diseases, lack of individual consent of the patient to conduct the study. All patients were matched according to age and sex. The investigation was carried out in accordance with the ethical principles of conducting scientific research and principles of the Helsinki Declaration.

To evaluate comorbidity, CirCom (Cirrhosis Comorbidity, Peter Jersen et al., 2014, http://gihep.com/calculators/hepatology/circom/), $\mathrm{CCl}$ (Charlson Comorbidity Index, Charlson Mary E. etal., 1987, Modified by Deyo, 1992, http://gihep.com/ charlson/), ECl (Elixhauser comorbidity index, http://orthotoolkit.com/elixhauser-comorbidity-measures/) indices were used [15]. CirCom is the scale developed exclusively for patients with LC. It includes the analysis with the consideration of 9 nosologies: chronic obstructive pulmonary disease, acute myocardial infarction, peripheral vascular lesions, epilepsy, drug addiction, apart from the alcohol, heart failure, non-metastatic or hematologic cancer, metastatic cancer, chronic kidney disease. The $\mathrm{ECl}$ index includes the analysis of comorbidity in chronic heart failure, arrhythmias, valvular defects, pulmonary embolism, peripheral vascular disorders, arterial hypertension, paralysis, neurodegenerative disorders, chronic pulmonary disease, diabetes, hypothyroidism, renal failure, liver disease, peptic ulcer disease, acquired immunodeficiency syndrome, lymphoma, metastatic cancer, non-metastatic cancer, rheumatoid arthritis, collagenosis, coagulopathy, obesity, oligotrophy, electrolyte disorders, deficiency anaemia, posthemorrhagic anaemia, alcohol abuse, drug abuse, psychosis, depression. Interpretation of the results is carried out in points or percentage: from -19 (the lower probability of death in a hospital) to 89 (the greater probability of death in a hospital).

The $\mathrm{CCl}$ is a point system for assessing age and certain concomitant diseases to prognosticate 10-year survival. It includes such concomitant diseases as myocardial infarction (acute or anamnestic) - 1 point, heart failure -1 point, peripheral vessel disease -1 point, cerebrovascular diseases -1 point, dementia - 1 point, bronchial asthma - 1 point, chronic non-specific lung diseases -1 point, diseases of the connective tissue -1 point, stomach ulcer and/ or duodenal ulcer - 1 point, liver disease with mild course (including alcoholic and non-alcoholic cirrhosis, biliary cirrhosis, chronic hepatitis) - 1 point, diabetes mellitus without terminal lesions of the internal organs -1 point, hemiplegia or paraplegia - 2 points, kidney disease -2 points, diabetes mellitus with terminal lesions of organs -2 points, malignant tumours -2 points, leukemia -2 points, lymphomas - 2 points, severe liver disease (hepatic coma, portal hypertension, varicose veins of the esophagus) -3 points, metastatic malignant tumours -6 points, acquired immunodeficiency syndrome -6 points. When it is calculated, the points corresponding to the concomitant disease are added, and 1 point is added for every decade of life when the patient exceeds fifty years of age. Each disease is assigned its value (points) depending on its connection degree with the 10-year mortality. According to the Charlson-Deyo index, in the absence of a concomitant disease, the risk of lethality is $12 \%, 1-2$ points $-26 \%, 3-4$ points $-52 \%$, more than 5 points - more than $85 \%$. 
Statistical processing of the obtained results was carried out using the software package Statistica v. 12.0 (StatSoft, USA, trial) and Microsoft Excel. The data were checked using the Shapiro-Wilk test. Since the data correspond to the normal type of distribution $(P>0.05)$, the interval $(\mathrm{M} \pm \mathrm{SD}$ ) was chosen as a measure of central tendency. The Student's t-test was used to test the null hypothesis of establishing the difference between the comparison groups. Statistical processing of qualitative data was carried out by calculating the frequency of the studied trait per 100 people in the survey. The reliability of the difference in data in the comparison groups was assessed by calculating the compliance criteria $X^{2}$. For quantitative data, the correlation was estimated using the Pearson parametric method of paired correlation; and for qualitative data, the Spearman's nonparametric method was used. Statistically significant differences were considered at $P<0.05$. To compare the likelihood of completion, depending on the risk factor, relative risk was used.

\section{Results}

Analyzing the structure of the concomitant pathology in patients with ALC associated with NAFLD depending on the class of compensation, it was found that patients of all classes suffered from gastrointestinal tract (GIT) disorders the most frequently, in the second place - the pathology of the nervous system, in the third - the pathology of the respiratory organs, in the fourth - cardiovascular disorders, in the fifth - the pathology of the urinary system, in the sixth - obesity, in the seventh - endocrine disorders. However, analyzing the structure of the concomitant pathology in groups I and II separately, it turned out that the comorbidity was changing: in patients of group I in the first, second and third place are the pathologies of the gastrointestinal tract, nervous and respiratory system respectively, in the fourth place - diseases of the urinary system, in the fifth - disorders of the cardiovascular system, in the sixth - endocrine disorders, there was no obesity; in patients of group II in the first and second places were also diseases of the gastrointestinal tract and the nervous system respectively, in the third place - cardiovascular disorders, in the fourth - respiratory disorders, in the fifth - lesions of the urinary system, in the sixth - obesity, in the seventh endocrine disorders.

Structuring comorbidities depending on the class of compensation leads to the following situation: the disorders of gastrointestinal tract and nervous system dominate in patients of groups IA and IB; in patients of group IIA the disorders of the gastrointestinal tract, nervous system, obesity and cardiovascular disease; in patients of group IIB - the disorders of the gastrointestinal tract, nervous system and cardiovascular disease; in patients in group IC there were disorders of the gastrointestinal tract, nervous system, respiratory and urinary system, in patients of group IIC diseases of the gastrointestinal tract, nervous and cardiovascular system, respiratory system, urinary system dominated. Endocrine disorders prevailed in patients of groups IIB and IIC. Thus, the combination of ALD and NAFLD was accompanied by more common disorders of the gastrointestinal tract, nervous, cardiovascular and respiratory systems, urinary tract, endocrine system and obesity.
Among the diseases of the gastrointestinal tract, chronic gastroduodenitis occurred in $91.0 \%$ and $90.5 \%$ of patients of groups I and II, respectively; stomach ulcer - in $9.0 \%$ and $4.8 \%$ of people of groups I and II, respectively; duodenal peptic ulcer - in $10.3 \%$ and $9.5 \%$ of persons of groups I and II, respectively; chronic cholecystitis - in $84.6 \%$ and $94.4 \%$ of patients of groups I and II, respectively; chronic pancreatitis - in $96.1 \%$ and $93.6 \%$ of patients in groups I and II, respectively; $19(31.1 \%)$ and $31(37.8 \%)$ persons of $\mathrm{IB}+\mathrm{C}$ and IIB+C groups, respectively, suffered from bleeding esophageal varices; $33.3 \%$ and $17.5 \%$ of patients in groups I and II, respectively, were hospitalized to the surgical department for pancreatic necrosis; spontaneous bacterial peritonitis was diagnosed in $17.4 \%$ and $26.5 \%$ of the patients of groups IC and IIC respectively.

Pathology of the nervous system was manifested by encephalopathy in $52.9 \%, 100 \%, 100 \%$ of patients of groups IA, IB, IC, respectively and in $86.4 \%, 100 \%, 100 \%$ of patients of groups IIA, IIB, IIC, respectively; polyneuropathy was in $64.7 \%, 100 \%, 100 \%$ of persons of groups IA, $\mathrm{IB}, \mathrm{IC}$, respectively, and in $88.6 \%, 100 \%, 100 \%$ of persons in groups IIA, IIB, IIC, respectively; transient ischemic attack in the history was in $6.8 \%, 10.4 \%, 14.7 \%$ of patients of groups IIA, IIB, IIC, respectively and in $8.7 \%$ of group IC; 2 patients in group IIB and 3 patients in group IIC had a stroke of the brain (Table 1). Violations in the respiratory system were structured as follows: chronic bronchitis was in $17.6 \%, 21.1 \%, 47.8 \%$, of patients in groups IA, IB, IC and $40.9 \%, 52.1 \%, 82.4 \%$ of persons of groups IIA, IIB, IIC, respectively; pneumonia was in $5.3 \%$ and $21.7 \%$ of patients in groups IB and IC and in $8.3 \%$ and $55.9 \%$ of patients in groups IIB, IIC, respectively; hydrothorax was observed in subcompensation and decompensation of the disease and was diagnosed in $13.2 \%$ and $82.6 \%$ in groups IB and IC, respectively and in $18.8 \%$ and $100 \%$ of patients of groups IIB, IIC, respectively; pleurisy was in $2.1 \%$ and $35.3 \%$ of patients of groups IIB, IIC, respectively and in $17.4 \%$ in group IIC. The following cardiovascular system pathologies in the examined patients were revealed: $5(10.4 \%)$ and 6 (17.6\%) persons of groups IIB and IIC, respectively, had a myocardial infarction in the history; hypertonic disease (HD) was in 2 (11.8\%), 2 (5.3\%) patients of groups IA and $\mathrm{IB}$, respectively, as well as in 28 (63.6\%), 37 (77.1\%) and $29(85.3 \%)$ of patients of groups IIA, IIB, IIC, respectively; ischemic heart disease (IHD) was in $5(13.1 \%)$ and 4 (17.4\%) persons of groups IB and IC, respectively, and in $23(52.3 \%), 42(87.5 \%)$ and 34 (100\%) persons of groups IIA, IIB and IIC, respectively; atrial fibrillation (AF) was in 2 (4.5\%), $6(12.5 \%), 13(38.2 \%)$ of patients of groups IIA, IIB and IIC, respectively; cardiovascular insufficiency was in $14(36.8 \%)$ and $17(73.9 \%)$ persons of IB and IC groups and in $34(77.3 \%), 48(100 \%), 34(100 \%)$ people of groups IIA, IIB, IIC, respectively; ultrasound examination revealed atherosclerotic lesions of the common carotid artery in 7 (15.9\%), $11(22.9 \%)$ and 19 (55.9\%) patients of groups IIA, IIB and IIC, respectively. Among the pathologies of the urinary system there were chronic kidney disease (CKD) in $4(10.5 \%), 18(78.3 \%)$ patients of groups IB and IC, as well as in 14 (31.8\%), 29 (60.4\%) and 34 (100\%) persons of groups IIA, IIB, IIC, respectively; kidney cysts were in 2 $(4.5 \%), 7(14.6 \%), 9(26.5 \%)$ patients of groups IIA, IIB, IIC, and 4 (17.4\%) patients of group IC. Type II diabetes 


\section{Оригинальные исследования}

Table 1. The structure of concomitant pathology in patients with alcoholic liver cirrhosis and in combination of alcoholic liver cirrhosis with nonalcoholic fatty liver disease

\begin{tabular}{|c|c|c|c|c|c|c|}
\hline \multirow[t]{4}{*}{ Concomitant diseases } & \multicolumn{6}{|c|}{ Stage of LC by Child-Pugh score } \\
\hline & Gr. IA & Gr. IIA & Gr. IB & Gr. IIB & Gr. IC & Gr. IIC \\
\hline & $n=17$ & $n=44$ & $n=38$ & $n=48$ & $n=23$ & $n=34$ \\
\hline & abs $/ \%$ & abs $/ \%$ & abs $/ \%$ & abs $/ \%$ & abs $/ \%$ & abs $/ \%$ \\
\hline Hypertonic disease & $2 / 11.8$ & $28 / 63.6$ & $2 / 5.3$ & $37 / 77.1$ & - & $29 / 85.3$ \\
\hline Ischemic heart disease & - & $23 / 52.3$ & $5 / 13.1$ & $42 / 87.5$ & $4 / 17.4$ & $34 / 100$ \\
\hline Cardiovascular failure & - & $34 / 77.3$ & $14 / 36.8$ & $48 / 100$ & $17 / 73.9$ & $34 / 100$ \\
\hline Transient ischemic attack & - & $3 / 6.8$ & - & $5 / 10.4$ & $2 / 8.7$ & $5 / 14.7$ \\
\hline Stroke of the brain in the history & - & - & - & $2 / 4.2$ & - & $3 / 8.8$ \\
\hline Myocardial infarction in the history & - & $2 / 4.5$ & - & $5 / 10.4$ & - & $6 / 17.6$ \\
\hline Atherosclerotic lesions of the common carotid artery & - & $7 / 15.9$ & - & $11 / 22.9$ & - & $19 / 55.9$ \\
\hline Atrial fibrillation & - & $2 / 4.5$ & - & $6 / 12.5$ & - & $13 / 38.2$ \\
\hline Type II diabetes mellitus & - & $2 / 4.5$ & - & $5 / 10.4$ & $1 / 4.3$ & $7 / 20.6$ \\
\hline Obesity & - & $41 / 93.2$ & - & $23 / 47.9$ & - & - \\
\hline CKD & - & $14 / 31.8$ & $4 / 10.5$ & $29 / 60.4$ & $18 / 78.3$ & $34 / 100$ \\
\hline Kidney cysts & - & $2 / 4.5$ & - & $7 / 14.6$ & $4 / 17.4$ & $9 / 26.5$ \\
\hline Chronic pancreatitis & $14 / 82.3$ & $36 / 81.8$ & $38 / 100$ & $48 / 100$ & $23 / 100$ & $34 / 100$ \\
\hline Pancreonecrosis in the history & $4 / 23.5$ & $5 / 11.4$ & $13 / 34.2$ & $8 / 16.7$ & $9 / 39.1$ & $9 / 26.5$ \\
\hline Chronic cholecystitis & $12 / 70.6$ & $37 / 84.1$ & $31 / 81.6$ & $48 / 100$ & $23 / 100$ & $34 / 100$ \\
\hline Stomach peptic ulcer & $1 / 5.9$ & - & $3 / 7.9$ & $2 / 4.2$ & $3 / 13$ & $4 / 11.8$ \\
\hline Duodenal peptic ulcer & $2 / 11.8$ & $3 / 6.8$ & $2 / 5.3$ & $3 / 6.3$ & $4 / 17.4$ & $6 / 17.6$ \\
\hline Chronic gastroduodenitis & $10 / 58.8$ & $32 / 72.7$ & $38 / 100$ & $48 / 100$ & $23 / 100$ & $34 / 100$ \\
\hline Bleeding esophageal varices in the history & - & - & $8 / 21.1$ & $12 / 25$ & $11 / 47.8$ & $19 / 55.9$ \\
\hline Spontaneous bacterial peritonitis & - & - & - & - & $4 / 17.4$ & $9 / 26.5$ \\
\hline Encephalopathy & $9 / 52.9$ & $38 / 86.4$ & $38 / 100$ & $48 / 100$ & $23 / 100$ & $34 / 100$ \\
\hline Polyneuropathy & $11 / 64.7$ & $39 / 88.6$ & $38 / 100$ & $48 / 100$ & $23 / 100$ & $34 / 100$ \\
\hline Chronic bronchitis & $3 / 17.6$ & $18 / 40.9$ & $8 / 21.1$ & $25 / 52.1$ & $11 / 47.8$ & $28 / 82.4$ \\
\hline Pneumonia & - & - & $2 / 5.3$ & $4 / 8.3$ & $5 / 21.7$ & $19 / 55.9$ \\
\hline Hydrothorax & - & - & $6 / 13.2$ & $9 / 18.8$ & $19 / 82.6$ & $34 / 100$ \\
\hline Pleurisy & - & - & - & $1 / 2.1$ & $4 / 17.4$ & $12 / 35.3$ \\
\hline
\end{tabular}

Table 2. Distribution of patients with alcoholic liver cirrhosis and in combination of alcoholic liver cirrhosis with nonalcoholic fatty liver disease depending on age

\begin{tabular}{|c|c|c|c|c|c|c|c|c|}
\hline \multirow{3}{*}{$\begin{array}{l}\text { Class of liver cirrhosis } \\
\text { by Child-Pugh score }\end{array}$} & \multicolumn{3}{|l|}{ Group I } & \multirow[t]{2}{*}{$\mathrm{n}$} & \multicolumn{3}{|l|}{ Group II } & \multirow[t]{2}{*}{$\mathrm{n}$} \\
\hline & 25-44 у.о. & 45-59 у.о. & $60-75$ у.о. & & 25-44 y.o. & 45-59 у.о. & $60-75$ у.о. & \\
\hline & abs $/ \%$ & abs $/ \%$ & abs $/ \%$ & abs $/ \%$ & abs $/ \%$ & abs $1 \%$ & abs $1 \%$ & abs $/ \%$ \\
\hline A & $10 / 58.8$ & $5 / 29.4$ & $2 / 11.8$ & $17 / 21,8$ & $25 / 56.8$ & $15 / 34.1$ & $4 / 9.1$ & $44 / 34,9$ \\
\hline B & $18 / 47.4$ & $14 / 36.8$ & $6 / 15.8$ & $38 / 48,7$ & $25 / 52.1$ & $18 / 37.5$ & $5 / 10.4$ & $48 / 38,1$ \\
\hline C & $5 / 21.7$ & $12 / 52.2$ & $6 / 26.1$ & $23 / 29,5$ & $14 / 41.2$ & $15 / 44.1$ & $5 / 14.7$ & $34 / 27,0$ \\
\hline Total & $33 / 42.3$ & $31 / 39.7$ & $14 / 18$ & $78 / 38,2$ & $64 / 50.8$ & $48 / 38.1$ & $14 / 11.1$ & $126 / 61,8$ \\
\hline
\end{tabular}

Table 3. Results of analysis of $\mathrm{CCl}$, ECl, CirCom and Child-Pugh score in patients with alcoholic liver cirrhosis and in combination of alcoholic liver cirrhosis with nonalcoholic fatty liver disease

\begin{tabular}{|c|c|c|c|c|c|c|}
\hline \multirow[t]{4}{*}{ Score } & \multicolumn{6}{|c|}{ Class of liver cirrhosis by Child-Pugh score ( $\mathrm{M} \pm \mathrm{m})$} \\
\hline & \multicolumn{2}{|c|}{ Class A by Child-Pugh score } & \multicolumn{2}{|c|}{ Class B by Child-Pugh score } & \multicolumn{2}{|c|}{ Class $\mathrm{C}$ by Child-Pugh score } \\
\hline & Gr. I & Gr. II & Gr. I & Gr. II & Gr. I & Gr. II \\
\hline & $n=17$ & $n=44$ & $n=38$ & $n=48$ & $n=23$ & $n=34$ \\
\hline $\mathrm{CCl}$ & $\begin{array}{l}2.40 \pm 0.43 / \\
84.3 \pm 7.6 \%\end{array}$ & $\begin{array}{l}4.30 \pm 0.51 / \\
36.7 \pm 4.1 \%{ }^{1}\end{array}$ & $\begin{array}{l}3.60 \pm 0.54 / \\
47.2 \pm 4.9 \% \%^{4}\end{array}$ & $\begin{array}{l}5.40 \pm 0.52 / \\
18.1 \pm 2.6 \% 2.6\end{array}$ & $\begin{array}{l}7.20 \pm 0.35 / \\
0 \% 5.8\end{array}$ & $\begin{array}{l}10.10 \pm 2.36 / \\
0 \% 3,7,9\end{array}$ \\
\hline $\mathrm{ECl}$ & $\begin{array}{l}10.20 \pm 0.82 / \\
74.6 \pm 4.3 \%\end{array}$ & $\begin{array}{l}29.70 \pm 3.22 / \\
57.3 \pm 3.4 \% 1\end{array}$ & $\begin{array}{l}24.50 \pm 21.45 / \\
57.1 \pm 4.8 \%^{4}\end{array}$ & $\begin{array}{l}32.30 \pm 2.61 / \\
54.1 \pm 4.8 \%^{2.6}\end{array}$ & $\begin{array}{l}33.60 \pm 2.34 / \\
46.7 \pm 3.5 \% 5.8\end{array}$ & $\begin{array}{l}36.7 \pm 3.87 / \\
50.1 \pm 4.3 \% 3,7,9\end{array}$ \\
\hline CirCom & $0.85 \pm 0.37$ & $2.34 \pm 0.611$ & $2.09 \pm 0.64^{4}$ & $3.19 \pm 0.37^{2,6}$ & $2.53 \pm 0.44^{5.8}$ & $3.72 \pm 0.52^{3,7,9}$ \\
\hline Child-Pugh & $5.32 \pm 0.48$ & $6.53 \pm 0.38^{1}$ & $7.69 \pm 0.52^{4}$ & $9.31 \pm 0.54^{2,6}$ & $12.61 \pm 0.645 .8$ & $14.34 \pm 0.73^{3,7,9}$ \\
\hline
\end{tabular}

1: significance of the difference of indicators between groups IA and IIA $(P<0.05)$; : significance of the difference of indicators between groups IB and IIB $(P<0.05)$; 3 : significance of the difference of indicators between groups IC and IIC $(P<0.05) ; 4$ : significance of the difference of indicators between groups IA and IB $(P<0.05) ; 5$ : significance of the difference of indicators between groups IB and IC $(P<0.05)$; : significance of the difference of indicators between groups IIA and IIB $(P<0.05){ }^{7}$ : significance of the difference of indicators between groups IIB and IIC $(P<0.05)$; : significance of the difference of indicators between groups IA and IC $(P<0.05)$; : significance of the difference of indicators between groups IIA and IIC $(P<0.05)$. 
mellitus was found in $1(1.3 \%)$ and $14(11.1 \%)$ persons of groups I and II, respectively; obesity as a manifestation of metabolic abnormalities - in 41 (93.2 \%) and 23 (47.9\%) persons of groups IIA and IIB, respectively.

In terms of age, both groups did not differ $(P>0.05)$. Depending on the stage of compensation, age features were revealed (Table 2). In particular, among patients with a compensation stage more than half of the people were young, one third - middle aged; with a stage of decompensation there were $21.7 \%, 52.2 \%, 26.1 \%$ and $41.2 \%, 44.1 \%$, $14.7 \%$ of patients in groups I and II of young, middle and old age, respectively; with a stage of subcompensation there were $47.4 \%, 36.8 \%, 15.8 \%$ and $52.1 \%, 37.5 \%, 10.4 \%$ of patients in groups I and II of young, middle and old age, respectively. Among patients in group I, 14 persons (17.9\%) had one concomitant pathology, moreover $85.7 \%$ of them were under 45 years of age and had class $A$. One third of patients ( 24 persons $(30.8 \%$ ) of groups I, who were from 45 to 60 years old, had two concomitant pathologies. Patients of group IC, regardless of age, had 3 or more concomitant diseases. $23(46 \%)$ patients of groups IIA+B under the age of 45 years, had two concomitant pathologies. 27 (87.1\%) middle-aged patients, of groups IIA+B had more than 3 concomitant diseases. $14(70.0 \%)$ patients of group IIC, who were more than 45 years old, had 5 or more comorbid conditions. A two-way positive correlation ( $r s=+0.42$, $\mathrm{P}<0.001$ ) between the age of the patients and the number of concomitant diseases, as well as between the degree of compensation and the number of concomitant diseases was revealed ( $r s=+0.46, P<0.001$ ).

In calculating the polymorbidity and severity of the disease, the $\mathrm{CCl}, \mathrm{ECl}$, CirCom and Child-Pugh score were used (Table 3). The indicators of $\mathrm{CCl}$ score were 1.8, 1.5 and 1.4 times higher in groups IIA, IIB, IIC compared to patients of groups IA, IB, IC, respectively $(P<0.05)$. The indicators of $\mathrm{ECl}$ scores were 2.9, 1.3 and 1.1 times higher in patients of groups IIA, IIB, IIC compared to patients in groups IA, IB, $I C$, respectively $(P<0.05)$. CirCom score indicators were 2.7, 1.5 and 1.5 times higher in persons of groups IIA, IIB, IIC compared to patients in groups IA, IB, IC, respectively $(P<0.05)$. Child-Pugh score indicators were 1.2, 1.2 and 1.1 times higher in patients of groups IIA, IIB, IIC compared to patients in groups $I A, I B, I C$, respectively $(P<0.05)$.

Analysis of the interaction between the $\mathrm{CCl}, \mathrm{ECl}$, CirCom and Child-Pugh scores using the Spearman's test, showed their significant correlation: between $\mathrm{CCl}$ and $\mathrm{ECl}$ rs $=+0.56$, between $\mathrm{CCl}$ and CirCom rs $=+0.48$, between $\mathrm{CCl}$ and Child-Pugh score $\mathrm{rs}=+0.62$, between $\mathrm{ECl}$ and $\mathrm{CirCom} r s=+0.52$, between $\mathrm{ECl}$ and Child-Pugh score rs $=+0.59$, between CirCom and Child-Pugh score $r s=+0.64$ (for all $P<0.05$ ). The number of concomitant pathologies in patients with LC significantly increased the risk of death from the causes which are not related to the LC (RR: 5.872; $95 \%$ Cl: 1.866-18.477).

During 4 years observation period, 35 patients (17.2\%) have died: 7 (19.4\%) and $29(80.6 \%)$ patients of groups I and II, respectively. 19 (52.8\%) persons died of the LC complications (bleeding from varicose veins of the esophagus (4 and 2 persons in groups II and I, respectively), hepatic failure ( 3 and 1 persons in groups II and I, respectively), hepatic-renal failure ( 4 and 2 persons of groups II and I, respectively), sepsis (2 and 1 person in groups II and I, respectively) and 17 (47.2\%) persons from other causes (pancreatic necrosis (2 and 1 persons of groups II and I respectively), myocardial infarction (3 persons of group II), thrombembolia of the pulmonary artery ( 3 persons of group II), acute heart failure (2 persons of group II), stroke of the brain ( 3 persons of group II), mesenteric ischemia (2 persons in group II), HCC (1 persons in group II)). A significant difference in comorbidity indices of $\mathrm{CCl}, \mathrm{ECl}$, CirCom and the total number of concomitant diseases between the groups of patients, who died from the causes, which are not related to the LC and those, who stayed alive till the end of the observation period $(P<0.05)$, was proved.

\section{Discussion}

According to our research and research of P. Jepsen (2014) the comorbidity affects the prognosis of cirrhosis patients [15]. The structure of concomitant pathology in patients with ALD associated with NAFLD depending on the compensation and age of patients was analyzed.

The cardiovascular diseases (particularly acute myocardial infarction, peripheral arterial disease, and heart failure, coronary disease), lung diseases (particularly chronic obstructive lung disease), gastrointestinal disease (particularly chronic pancreatitis, complicated peptic ulcer), chronic kidney disease, connective tissue disease, psychiatric disease, non-hepatic cancer, venous thromboembolism and diabetes were strong predictors of mortality in the study of Jepsen (2014) and Keeffe (2003).

In our study it was found out that people with ALD in combination with NAFLD suffered more often than people with ALD from other diseases of the digestive tract, nervous, cardiovascular, respiratory and urinary systems, as well as obesity and endocrine disorders. Patients in both groups suffered from the disorders of the gastrointestinal tract and the nervous system more often than others. However, depending on the degree of the disease compensation, there were differences between the patients in groups I and II: people of group II had the disorders of the cardiovascular, respiratory, urinary, endocrine systems more frequently. More than half of the people in group I with compensation stages $A$ and $B$ were diagnosed with diseases of the digestive tract and nervous systems. More than half of patients with the stages of compensation and subcompensation, when combined ALD and NAFLD, had diseases of the digestive tract, nervous, cardiovascular, urinary, respiratory systems and obesity. Chronic gastroduodenitis, chronic cholecystitis and chronic pancreatitis were the most typical disorders of gastrointestinal tract in patients of all classes. Most patients of group II had hypertonic disease, IHD, cardiovascular insufficiency, and $\mathrm{AF}$ in $16.7 \%$, atherosclerotic lesions of the common carotid arteries in $29.4 \%$ of the cases, stroke of the brain in $4 \%$, myocardial infarction in $10.3 \%$, transient ischemic attacks of the brain in $11.9 \%$, obesity with the stages of compensation and subcompensation in $69.6 \%$ of patients. $11.1 \%$ and $1.3 \%$ of patients in groups II and II respectively, suffered from type II diabetes mellitus; $14.2 \%$ and $5.1 \%$ of patients in groups II and I respectively had kidney cysts; $61.1 \%$ and $28.2 \%$ in groups $I I$ and I, respectively, had CKD; in $56.3 \%$ and $28.2 \%$ of people in groups II and I, respectively, chronic bronchitis was diagnosed. Patients in group II 
more often experienced pleurisy, pneumonia, spontaneous bacterial peritonitis. Manifestations of encephalopathy and polyneuropathy were also more pronounced in patients of group II.

In study of Fortin (2005) the prevalence of comorbidities was $69 \%$ of young people (18-44 years), up to $93 \%$ among middle-aged (45-64 years), and up to $98 \%$ in patients with an older age group (over 65) with LC. In our study age peculiarities of the distribution of patients depending on the stage of compensation showed that twice as many persons of group II, compared with group I with a stage of decompensation, were less than 45 years old. Most people of group I with stages $B$ and $C$ were over 60 years old. 23 (46\%) patients of groups IIA+B, who were less than 45 years old, had two concomitant diseases, which 2.6 times exceeded the number of such persons in group II. More than $80 \%$ of middle-aged patients in group IIA+B had more than 3 concomitant diseases, which is 1.7 times more than in group I. $70 \%$ of patients with a combination of ALD and NAFLD at the stage of decompensation of cirrhosis had 5 or more comorbid states. The direct relationship between the age of patients and the number of concomitant diseases, as well as between the degree of compensation and the amount of concomitant pathology leads to a more severe course of the disease in people with a combination of ALD and NAFLD at the stage of cirrhosis. The reliable correlation between the $\mathrm{CCl}, \mathrm{ECl}$, CirCom scales of comorbidity and the Child-Pugh degree of the disease severity, allow recommending their use in characterizing the comorbidity and prognosticating in ALD associated with NAFLD at the stage of cirrhosis. We also found out the statistical significance of concomitant pathology, which is not related to complications of LC, for fatal outcome: the relative risk of death in such patients is 7.5 times higher.

4-year observation showed that $80.6 \%$ of patients with a combination of ALD and NAFLD at the stage of cirrhosis have died, which 4 times exceeded the number of those who had alcoholic LC. $52.8 \%$ of them died from LC complications (bleeding from varicose veins of the esophagus, liver failure, liver and kidney insufficiency, sepsis), $47.2 \%$ died from other causes: pancreatic necrosis, myocardial infarction, thromboembolism of the pulmonary artery, acute cardiac insufficiency, stroke of the brain, mesenteric thrombosis, HCC.

Thus, in combination of ALD and NAFLD, the number of concomitant non-LC-related pathologies that cause a more severe course raises and increases the risk of death from such conditions as pancreatic necrosis, myocardial infarction, thromboembolism of the pulmonary artery, acute heart failure, stroke of the head brain, mesenteric thrombosis, HCC.

Comorbidity in patients with alcoholic LC associated with $\mathrm{NADH}$, related and not related to the complications of the underlying disease, significantly complicates the treatment tactics and worsens the outlook. Therefore, the early detection and treatment of concomitant pathologies is important for preventing the progression of decompensation and the development of complications.

\section{Conclusions}

1. More than $90 \%$ of patients with ALC had such concomitant diseases as chronic gastroduodenitis, chronic cholecystitis, and chronic pancreatitis.
2. More than $70 \%$ of patients with combination of ALD and NAFLD at the stage of cirrhosis had concomitant diseases and cardiovascular complications.

3. Patients with combination of ALD and NAFLD had disorders of the respiratory, urinary, endocrine, and nervous systems, as well as bacterial complications, including pleurisy, pneumonia, spontaneous bacterial peritonitis, more frequently.

4. It is useful to use the $\mathrm{CCl}, \mathrm{ECl}$, CirCom scales of comorbidity, and Child-Pugh degree of the disease severity in considering the comorbidity level and severity of the disease in order to improve patient management and to predict the course of ALD associated with NAFLD at the stage of cirrhosis.

5. The incidence of comorbid diseases increases with age and significantly increases the risk of death from causes which are not associated with the complications of the LC.

The perspective for the further scientific research is to study the features of laboratory manifestations of alcoholic liver disease at the cirrhosis stage associated with non-alcoholic fatty liver disease depending on disease compensation.

\section{Funding}

The study is carried out according to the plan of scientific works of Ivano-Frankivsk National Medical University and is a fragment of research work: "Diseases of internal organs in modern conditions, with combined pathology and lesions of target organs: features of the course, diagnosis and treatment", number of state registration: $0115 \mathrm{U} 000995$.

Conflicts of interest: authors have no conflict of interest to declare. Конфлікт інтересів: віАсутній.

Надійшла Ао редакції / Received: 06.05.2019

Після Аоопрацювання / Revised: 04.10.2019

Прийнято Ао Аруку / Accepted: 10.10.2019

Information about authors:

Matkovska N. R., MD, PhD, Assosiate Professor of the

Department of Therapy and Family Medicine of Postgraduate Education Faculty, Ivano-Frankivsk National Medical University, Ukraine.

Virstiuk N. H., MD, PhD, DSc, Professor, Head of the Department of Internal Medicine of Stomatological Faculty named after professor M. M. Berezhnytskyi, Ivano-Frankivsk National Medical University, Ukraine.

Balan U. V., MD, PhD, Assistant of the Department of Internal Medicine No. 1, Immunopathology and Allergology named after academician Ye. M. Neiko, Ivano-Frankivsk National Medical University, Head of Clinical and Diagnostic Laboratory of the Regional Clinical Hospital, Ivano-Frankivsk, Ukraine.

\section{Відомості про авторів:}

Матковська Н. Р., канА. меА. наук, Аоцент каф. терапії і сімейної меАицини післяАипмомної освіти, Івано-Франківський національний медичний університет, Україна.

Вірстюк Н. Г., А-р меА. наук, професор, зав. каф. внутрішньої медицини стоматологічного факультету імені професора М. М. Бережницького, Івано-Франківський національний медичний університет, Україна.

Балан У. В., канА. меА. наук, асистент каф. внутрішньої медицини № 1, кмінічної імунології та алергології імені академіка Є. М. Нейка, Івано-Франківський національний медичний університет, зав. клініко-діагностичної лабораторії, Івано-Франківська обласна кмінічна лікарня, Україна. 
Сведения об авторах:

Матковская Н. Р., канА. меА. наук, Аоцент каф. терапии и семейной меАицины послеАипломного образования, ИваноФранковский национальный медицинский университет, Украина.

Вирстюк Н. Г., А-р меА. наук, профессор, зав. каф. внутренней медицины стоматологического факультета имени профессора М. М. Бережницкого, Ивано-Франковский национальный медицинский университет, Украина.

Балан У. В., канА. меА. наук, ассистент каф. внутренней медицины № 1, клинической иммунологии и аммергологии имени академика Е. М. Нейко, Ивано-Франковский национальный медицинский университет, зав. клиникоАиагностической мабораторией, Ивано-Франковская областная клиническая больница, Украина.

\section{References}

[1] Schiavo, L., Busetto, L., Cesaretti, M., Zelber-Sagi, S., Deutsch, L., \& lannelli, A. (2018). Nutritional issues in patients with obesity and cirrhosis. World Journal of Gastroenterology, 24(30), 3330-3346. https:// doi.org/10.3748/wjg.v24.130.3330

[2] MOZ Ukrainy, \& DU «UISD MOZ Ukrainy». (2018). Shchorichna dopovid pro stan zdorovia naselennia, sanitarno-epidemichnu sytuatsiiu ta rezultaty diialnosti systemy okhorony zdorovia Ukrainy. 2017 rik [The annual report on the health of the population, sanitary and epidemic situation, and the results of the health care system of Ukraine. 2017]. Medinform. [in Ukrainian].

[3] Sharabchiev, Yu. T., Antipov, V. V., \& Antipova, S. I. (2014). Komorbidnost' - aktual'naya nauchnaya i nauchno-prakticheskaya problema meditsiny XXI veka [Comorbidity is an actual scientific and practical problem of the 21st century medicine]. Meditsinskie novosti, (8), 6-11. [in Russian].

[4] DuGoff, E. H., Canudas-Romo, V., Buttorff, C., Leff, B., \&Anderson, G. F. (2014). Multiple Chronic Conditions and Life Expectancy. Medical Care, 52(8), 688-694. https://doi.org/10.1097/mlr.0000000000000166

[5] Abrahamovych, O., Fayura, O., \& Abrahamovych, U. (2015). Komorbidnist: suchasnyi pohliad na problemu; klacyfikatsiia (povidomlennia pershe) [Comorbidity: a Modern View on the Problem; Classification (first notice)]. Lvivskyi klinichnyi visnyk, (1), 56-64. [in Ukrainian].

[6] Oganov, R. G., Simanenkov, V. I., Bakulin, I. G., Bakulina, N. V., Barbarash, O. L., Boytsov, S. A., Boldueva, S. A., Garganeeva, N. P., Doshchitsin, V. L., Karateev, A. E., Kotovskaya, Yu. V., Lila, A. M., Lukyanov, M. M., Morozova, T. E., Pereverzev, A. P., Petrova, M. M., Pozdnyakov, Yu. M., Syrov, A. V., Tarasov, A. V., ... Shalnova, S. A. (2019). Komorbidnaya patologiya $v$ klinicheskoi praktike. Algoritmy diagnostiki i lecheniya [Comorbidities in clinical practice. Algorithms for diagnostics and treatment]. Kardiovaskulyarnaya terapiya i profilaktika, 18(1), 5-66. http://dx.doi.org/10.15829/1728-8800-2019-1-5-66 [in Russian]

[7] Gudkov, R. A., \& Konovalov, O. E. (2015). Komorbidnost', mul'timorbidnost', polipatii - tri vzglyada na sochetannye patologii [Comorbidity, multimorbidity, polypathy - three views on the combined pathology]. Vestnik RUDN, seriya Meditsina, (1), 39-45. [in Russian].

[8] Fadieienko, G. D., \& Nessen, A. O. (2015). Komorbidnist ta intehratyvna rol terapii vnutrishnikh khvorob [Comorbidity and integration role of therapy of internal diseases]. Ukrainskyi terapevtychnyi zhurnal, (2), 7-15. [in Ukrainian].

[9] Sevinsky, R. E., Stewart, D. W., \& Harirforoosh, S. (2017). Nonsteroidal anti-inflammatory drugs: Is there a link between cardiovascular and renal adverse effects? Journal of Integrative Nephrology and Andrology, 4(1), 1-2. https://doi.org/10.4103/jina.jina_2_17

[10] National Institute for Health and Care Excellence (2016, September 21). Multimorbidity: clinical assessment and management. NICE. https:// www.nice.org.uk/guidance/ng56

[11] Fialla, A. D., Israelsen, M., Hamberg, O., Krag, A., \& Gluud, L. L. (2015). Nutritional therapy in cirrhosis or alcoholic hepatitis: a systematic review and meta-analysis. Liver International, 35(9), 2072-2078. https://doi. org/10.1111/liv. 12798

[12] Parikh, N. S., Navi, B. B., Schneider, Y., Jesudian, A., \& Kamel, H. (2017). Association Between Cirrhosis and Stroke in a Nationally Representative Cohort. JAMA Neurology, 74(8), 927-932. https://doi. org/10.1001/jamaneurol.2017.0923

[13] Wu, W. K. K., Zhang, L. \& Chan, M. T. V. (2018). Autophagy, NAFLD and NAFLD-Related HCC. In J. Yu (Ed.). Obesity, Fatty Liver and Liver Cancer: Vol. 1061. Advances in Experimental Medicine and Biology (pp. 127-138). Springer. https://doi.org/10.1007/978-981-10-8684-7 10

[14] Tsai, M. -C., Yang, T. -W., Wang, C. -C., Wang, Y. -T., Sung, W. -W. Tseng, M. -H., \& Lin, C. -C. (2018). Favorable clinical outcome of nonalcoholic liver cirrhosis patients with coronary artery disease: A population-based study. World Journal of Gastroenterology, 24(31), 3547-3555. https://doi.org/10.3748/wjg.v24.i31.3547
[15] Jepsen, P., Vilstrup, H., \& Lash, T. L. (2014). Development and Validation of a Comorbidity Scoring System for Patients With Cirrhosis. Gastroenterology, 146(1), 147-156. https://doi.org/10.1053/j. gastro.2013.09.019 